\title{
Increasing Role of Nuclear weapon free Zones: Challenges and Opportunities*
}

\author{
By Michael Hamel-Green (Australia)
}

\begin{abstract}
$\Gamma^{b}$ September-October 2006 the world witnessed two separate but very significant events for the future direction of nuclear to proliferation and the threat of nuclear war.

One received huge international publicity - provoking almost universal condemnation and outrage in the international community, especially from the Western nuclear powers. The other was praised by many in the arms control and disarmament commuity inside and outside the UN, but virtually ignored by the mainstream media, and actively opposed by the Western nuclear powers.

The first event was the underground test conducted by North Korea on October 9th 2006, viewed by the North Korean regime as a measure designed "for bolstering its war deterrent for self-defence" in the context of what it perceives as a "US threat" and "hostile policy"1, but perceived by both other regional states and the intemational commuity as a highly destabilizing move that could trigger a regional muclear arms race, since both South Korea and Japan have the technical capabilities to rapidly acquire nuclear weapons.

The second event was at Semipalatinsk, Kazakhstan, on September 8th 2006, where the five Central Asia states, Kazakhstan, Kyrgystan, Tajikistan, Turkmenistan, and Uzbekistan signed a treaty to establish the first nuclear weapon-free zone wholly located in the Northern

* Paper prepared for IPPNW/North Asia NWFZ Regional Meeting June 21-22 2007, Ulan Bator, Mongolia

${ }^{1}$ DPRK, "DRG Foreign Ministry Spokesman on US Moves Concerning Its Nuclear Test", KCNA, 11/10/06
\end{abstract}


Hemisphere $e^{2} .2$ The ceremony took place in the highly symbolic location of one of the former Soviet Union's most important nuclear test sites, and was the culmination of nine years of negotiation that overcame both intemal differences and many (though not all) extemal nuclear weapon state reservations. It effectively denuclearises a highly strategic region that has the nuclear materials (uranium and even stocks of plutonium), research facilities, and previous nuclear experience and technical expertise, to develop nuclear weapons. As Parish and Potter note in a recent analysis of the new zone:

"To a greater extent than the previous NWFZs, the one in Central Asia will showcase a commitment to nuclear disarmament by a group of states which previously had nuclear weapons on their territory and continue to live in a nuclear-armed neighborhood. Surrounded by Russian, Chinese, Pakistani, Indian and Israeli nuclear weapons, and housing Russian and U.S. military bases, the new zone will serve as a powerful example of non-proliferation - an important antidote and positive counter-example to Iranian and North Korean nuclear brinkmanship. It will also be the first NWFZ located entirely in the northern hemisphere. ${ }^{3}$

Despite the extraordinary achievement of five new nations, assisted by the United Nations and non-proliferation NGOs in successfully negotiating such a treaty in the face of ambivalence, obstructionism and even outright resistance by various of the nuclear powers, and despite the alleged concern by major powers and media opinion leaders about nuclear weapons spreading and falling into the wrong hands, there was a deafening silence in the international media about a major nonproliferation initiative that points the way for other regions, not least Northeast Asia. It seems the preoccupation with coercive and preemptive approaches to controlling proliferation favoured by the Bush Administration has blinded many in the media to the possibilities and realities of cooperative regional approaches to reducing nuclear threats.

${ }^{2}$ UN Regional Centre for Peace and Disarmament in Asia and the Pacific, "Central Asian Nuclear-Weapon-Free Zone (CANWFZ)", UN Department of Disarmament Affairs website, disarmament.un.org/rpcd/centasia.htm, 2006.

${ }^{3}$ Parrish, Scott \& Potter, William, "Central Asian States Establish Nuclear-WeaponFree Zone Despite U.S.Opposition", CNS Research Story, Center for Nonproliferation Studies, aNS website, cns.miis.edu/pubs/week/, september 52006 


\section{Progress in regional denuclearization}

There has, in fact, been steady, if slow, progression in regional demuclearisation since the first nuclear weapon free zone in a populated area was established in Latin America in 1967. The Nobel prize winning architect of that zone, the Mexican diplomat, Alfonso Garcia Robles, argued that not only would such zones contribute to reducing horizontal proliferation in specific regions, but also contribute to global nuclear disarmament through gradually diminishing the areas of the world for which nuclear weapons are viewed as a necessary part of national or regional security.

Much of Robles' vision has already been achieved. Almost all of the Southern Hemisphere is now covered by regional nuclear-free or nuclear weapon-free zones, including the Latin American NWFZ (Tlatelolco Treaty, 1967), South Pacific NWFZ (Rarotonga Treaty, 1985), Southeast Asian NWFZ (Bangkok Treaty, 1996) African NWFZ (Pelindaba Treaty, 1996), with the two latter NWFZs extending into the Northern Hemisphere. The new Central Asian NWFZ (Semipalatinsk, 2006) expands the NWFZ concept to a significant regional grouping wholly in the Northern Hemisphere. No nuclear weapons may be developed or stationed on land anywhere in the regions covered by these zones, although nuclear weapons transit at sea is still permitted by most of the zones. At the same time, the zones seek to constrain vertical proliferation in the form of nuclear threats from the existing nuclear powers by seeking international recognition through the UN and binding protocols from the relevant nuclear states providing negative security assurances (NSAs) in the form of undertakings not use or threaten to use nuclear weapons against zonal members.

Other zones have been proposed for such regions as Central Europe, Northern Europe, the Baltic region, the Middle East, South Asia and Northeast Asia, but have so far not advanced, either because of lack of regional consensus, or due to the opposition of major powers. Nevertheless, there has been strong support from the international cormunity and many of the relevant regional states for the Middle East and South Asia NWFZ proposals, and for at least the denuclearisation of the Korean Peninsula within the Northeast Asia region.

We tend to be preoccupied with proliferation bad news stories the setbacks posed by the 1998 Indian and Pakistan nuclear tests and now the 2006 North Korean nuclear tests, in each case confirming the 
long suspected nuclear weapon capabilities of these countries. But the non-proliferation contribution of regional, and individual state NWFZs (such as Mongolia and New Zealand) has been less well appreciated.

The case of the very first NWFZ, the 1967 Tlatelolco Treaty, is instructive, particularly since the zone was originally negotiated in a regional context, like Northeast Asia, where there were tensions between major nuclear-capable regional states. Brazil and Argentina were involved in nuclear competition, and initially did not assume active membership of the treaty; however, after lengthy negotiations, they eventually assumed their full obligations under the Treaty in 1994-95, following the advent of civilian governments in both countries, and increasing bilateral cooperation during the $1980 \mathrm{~s}^{4}$. The Treaty most certainly played a regional role in establishing, promoting and maintaining legally binding non-proliferation norms, providing for region-wide verification and compliance mechanisms, and improving security from extemal nuclear threats by creating a mechanism for negative security assurances from the nuclear powers. In the latter case, all five muclear powers have now signed and ratified undertakings not to use or threaten to use nuclear weapons against members of the zone. The Treaty has also provided a number of other regional security benefits in the form of providing a regional forum on nuclear and arms control issues, improving transparency on nuclear and arms control issues, and providing means of promoting arms control and disarmament in UN and other intemational forums (as for example treaty members' role in hosting the 2005 Tlatelolco Conference of NWFZ zonal states) .

More generally, NWFZs have served to address a number of nonproliferation and disarmament objectives. In terms of horizontal proliferation, they have dramatically reduced the areas of potential nuclear weapon proliferation and thereby made the remaining proliferation problems somewhat more manageable. They also serve as a legal buffer against the potential collapse of central non-proliferation regimes, although such a collapse might in turn lead to abrogation of regional agreements as well, depending on the regional circumstances. Further, they provide normative and legally binding means for ensuring

${ }^{4}$ For a detailed discussion of the changing stances of Brazil and Argentina, and the role of the Tlatelolco Treaty, see Reiss, Mitchell, Bridled Ambition: Why Countries Constrain Thei r Nuclear Capabilities, Woodrow Wilson Centre Press/John Hopkins University Press, Washington DC, 1995, pp.64-66 
that regional states adhere to more universal agreements and control systems, such as IAFA safeguards, thereby serving to fill regional gaps in some non-proliferation agreements (as, for example, in the encouragement of such Latin American NPT-hold out states as Brazil, Argentina and Cuba to sign up to the NPT and IAEA safeguards) . NWFZs have also reduced the potential fields of use or threat of use of nuclear weapons by states already possessing nuclear weapons. In the absence of legal binding non-use assurances by the nuclear powers to non-nuclear states, regional NWFZs have so far been the only means for securing such guarantees, although in the case of the SEANFZ and the new CANWFZ, most of the nuclear powers have not yet signed up, or even ratified the necessary protocols. ${ }^{5}$

In the case of negative security guarantees, it could be argued that there are no certainties here since only three of the existing zones have secured such guarantees from the nuclear powers, and some have signed but not yet ratified. However, the process of gaining such guarantees is, in itself, a lengthy negotiation process. Even in the case of the IANWFZ, which now has guarantees from all of the P5 nuclear powers, these were secured only after years of diplomatic negotiation and pressure through the UN General Assembly. In this case, it would be premature to assume that the SEANWFZ and the newest CANWFZ will not be able to secure such guarantees; rather it will depend on the continuing negotiations and international pressures for the P5 to sign the relevant protocols.

\section{Challenges}

Despite the obvious progress in establishing regional NWFZs, there are formidable challenges to further regional initiatives. These include: regional conflicts and tensions, especially in the Middle East, South Asia and Northeast Asia; existing nuclear proliferation within the region; the nature or availability of regional fonms for discussing and negotiating regional security issues; nuclear weapon state policies and resistance to specific zone initiatives; developing sufficient political will and civil society mobilization behind the proposals; developing zonal initiatives

${ }^{5}$ For fuller discussions of the security benefits and limitations of the existing zones, see Hamel-Green, Michael, Regional Initiatives on Nuclear- and WMD-Free Zones, United Nations Institute for Disarmament Research, Geneva, 2005, pp.3-12; and Parrish, Scott \& Preez, Jean Du, Nuclear-Weapon-Free Zones: Still a Useful Disarmament and NonProliferation Tool?, The Weapons of Mass Destruction Commission, 2005, pp.2-3. 
adapted to the changing nature of weapons of mass destruction and their means of delivery; and ensuring adequate control, compliance and verification mechanisms as part of zonal arrangements.

The most obvious challenge to further regional denuclearisation is the existence of severe regional conflicts or distrust, even though such conflicts make such demuclearization initiatives all the more urgent if a future nuclear catastrophe is to be averted. The three regions that stand out as having such conflicts are the Middle East, South Asia and Northeast Asia. In the Middle East, the Palestinian-Israel and Iraq conflicts are continuing to rage, and there is a gathering storm over Iran's intention to undertake large-scale uranium enrichment, with consequent implications for developing a nuclear weapons capability. In response to the long-standing Middle East NWFZ proposal, supported by most members of the UN, Israel does not oppose the proposal in principle but insists there must be peace settlements with the Palestinians, and its Arab neighbours before it is willing to enter into negotiations on a MENWFZ or the related Egyptian proposal of a ME Weapons of Mass Destruction Free Zone (WMDFZ) . Middle East developments are also beginning to spill over into other regions, with Russia and America in tension over American plans to deploy missile defence systems in Poland and other European countries, ostensibly in defence against Iranian nuclear-armed missiles.

While the Israeli position presents the resolution of regional conflicts as an insuperable precondition to regional denuclearisation agreements, there are staged or sequenced approaches that would protect the security of all parties at every stage, and, might, as envisaged by the UN Experts' Study of the issue, involve initial confidence-building measures (regional test ban, IAEA safeguards' acceptance, accession to NPT); nuclear weapon state advance negative nuclear security assurances; declarations of existing nuclear materials; extended negotiations on a regional NWFZ; positive security assurances to the parties from external powers; and development of effective regional verification systems. ${ }^{6}$

In South Asia, the long standing conflict between India and Pakistan over Kashmir has been one factor that has stood in the way of regional denuclearisation, although in the past India-China tensions and rivalry played a critical part in India's initial acquisition of nuclear weapons and

${ }^{6}$ UN Document A/45/435, UN, New York, 1990; also see Prawitz, Jan and Leonard, James, A Zone Free of Weapons of Mass Destruction, UNIDIR, Geneva, 2004 
remains a justification for retaining them. The 1998 tests conducted by both India and Pakistan demonstrated their respective nuclear weapon capabilities and disregard for the Comprehensive Test Ban Treaty, and served to highlight the potential risk of a South Asian accidental nuclear war, or one triggered by a regional conflict. The region has also been the source of export of proliferation expertise and equipment through the clandestine network of assistance to such countries as Libya, North Korea and nuclear war, or Iran coordinated by the then head of Pakistan's nuclear program, Dr Abdul Qadeer Khan, during the 1990s.

In Northeast Asia, the major foci of concern and conflict have been North Korea's development of missile and nuclear capabilities in the context of long standing encirclement by US military and air bases in South Korea dating back to the Korean War, potential DPRK nuclearweapon-related exports to other regions, and unresolved tensions and conflicts between the two Koreas and Japan dating back to the Second World War. North Korea's underground testing of a nuclear weapon in October 2006 and continued testing of missiles in regional waters have proved major setbacks for the on-again off-again Six-Party talks aimed at resolving the nuclear issues, although a further promising agreement was struck in February 2007, and may still be implemented.

In all three of these regions, the challenges posed by regional conflicts and tensions have been exacerbated by (a) long standing, or new, muclear weapon proliferation in some of the countries of the region; (b) potential nuclear threats by extemal muclear weapon states; and (c) the absence of effective regional fonms or organizations for discussion and negotiation of arms control and disarmament issues.

In the case of the Middle East, Israel is believed to have acquired nuclear weapons in 1966-67, with two nuclear weapon devices on operational alert as early as the Six-Day 1967 Arab-Israeli War. The Israeli possession of nuclear weapons evidently failed to deter Arab countries in launching the 1973 War, nor Saddam Hussein in firing missiles at Israel during the Second Gulf War, nor most recently Hezbollah's rocket attacks on Israel during the 2006 Israeli invasion of Lebanon, yet serves as an incentive to other regional states, particularly Iran, to develop a nuclear capability in response (which would then retrospectively serve to "justify" the Israeli nuclear capability as a claimed deterrent). However, Israeli possession of nuclear weapons, and the security that Israelis rightly or wrongly perceive it as bringing to their 
country's continued existence, means that any progress on NWFZ would need to address Israeli security concems through intemational and great power positive and negative security guarantees, and effective and intrusive regional and international verification and compliance mechanisms.

In relation to nuclear threats posed by external nuclear powers, some Middle East regional states may well have had cause to be concemed by reports that the US placed its nuclear forces on alert during the 1973 war; and, more recently, by Seymour Hersh's April 2006 report that both the US Defence Science Board and the Pentagon were supporting the use of tactical B61 bunker-busting nuclear weapons on Iran if Iran continued on its current course of developing enrichment facilities and the means to produce nuclear weapons. ${ }^{7}$ This perceived extemal nuclear weapon threat by nuclear powers against non-nuclear regional states underlines the importance of advance negative security assurances as a first step in negotiating a MENWFZ.

The further barrier in the Middle East is the lack of a regional organization or forum for negotiating regional security and nuclear issues. The League of Arab states partially fills the role but does not, of course, include Israel and Iran; it has, however, strongly supported the MENWFZ and worked intensively to develop modalities and approaches that would be acceptable to all parties'. The "Quartet" of the US, Russia, European Union, and UN, which is currently seeking to facilitate a Palestinian-Israeli peace settlement, could also, potentially, play a role in facilitating a regional forum that would begin addressing regional muclear issues.

In South Asia, India and Pakistan have long standing nuclear weapon programmes, with India having first tested a nuclear weapon in 1974, and both India and Pakistan testing in 1998. The Indian program began in the early 1960s while the Pakistan program was started in 1972. An important extra regional nuclear threat from India's point of view is China, which first tested nuclear weapons in 1964, now possesses over

\footnotetext{
${ }^{7}$ Hersh, Seymour, "The Iran Plans: Would President Bush go to war to stop Tehran from getting the bomb?, New Yorker, April 82006.

${ }^{8} \mathrm{See}$, for example, the reports from the joint League of Arab States and UNIDIR 2003 Conference on "Building a Weapons of Mass Destruction Free Zone in the Middle East" in UNIDIR, Building a Weapons of Mass Destruction Free Zone in the Middle East: Global Non-Proliferation Regimes and Regional Experiences, UNIDIR, Geneva, UN, 2004
} 
400 nuclear weapons, and, in the past, has had border disputes with India. While South Asia does have a regional organization in the form of SAARC (South Asian Association for Regional Cooperation), this has been heavily dominated by India, although, more recently, the Jamuary 2004 SAARC meeting did serve to facilitate a bilateral Indian- Pakistan dialogue process on nuclear issues, which led to an agreed joint moratorium on further nuclear tests and establishment of a nuclear issues hotline between the two governments.

In Northeast Asia, proliferation has already occurred in the form of North Korea demonstrating its nuclear weapon possession in its 2006 underground nuclear test. In the past, South Korea has undertaken nuclear weapons development and research, but has so far not proceeded to actual nuclear weapon possession. Japan is still bound by its nonnuclear principles, but has a large stockpile of weapons-grade plutonium, and has the technical capability to move to nuclear weapon possession at very short notice. If the present negotiations to denuclearize North Korean and the Korean Peninsula through the Six-Party Talks are unsuccessful, there would be some incentive for Japan and South Korea to move to nuclear possession to "deter" North Korea, depending on Japanese and South Korean perceptions of how effective US security guarantees would be under their respective bilateral alliances. In terms of extra regional nuclear presence, the US for a long time deployed tactical nuclear weapons at its bases in South Korea, but has now removed them. However, perceptions of a continued nuclear and/or conventional threat from the US continue to influence North Korean policy, and provide an incentive for the regime to develop its own nuclear forces as a "deterrent" against an Iraqi-style invasion. As in the case of the Middle East, there is no Northeast Asian regional body that can act as a regular forum for negotiating nuclear and arms control issues. However, the ASEAN Regional Forum (ARF) has played a useful role, at least in relation to the discussion of confidence-building measures for the wide region, while the Six-Party Talks involving North Korea, China, South Korea, Japan, Russia and China recently agreed at its February 2007 meeting to establish, inter alia, a working group on a "Northeast Asia Peace and Security Mechani.sm" . ${ }^{9}$

${ }^{9}$ US State Department, "Initial Actions for the Implementation of the Joint Statement", 13th February 2007, US State Department website www.state.gov; also on Acronym Institute website, www.acronym.org.uk/docs/0702/doc.01.htm 
Beyond the challenges posed by regional conflicts, existing proliferation within a region, and the lack of effective regional organizations and negotiation forums, a key challenge for NWFZ establishment is the attitude of the nuclear weapon states, particularly the P5 (US, Russia, China, UK and France) .

While all P5 nuclear weapon states have in the past voiced in principle support for NWFZs, and all have now signed up to the Latin American, South Pacific and African NWFZs (with some ratifications still outstanding), they have been very selective and ambivalent about supporting some specific zones, despite their expressed concerns about non-proliferation. In many cases, they have put their own perceived short-term nuclear and military interests ahead of the need to prevent whole regions going nuclear, or denuclearize existing regions where proliferation has already occurred.

This is especially so in the case of the United States, which, even under the Clinton Administration, did not sign up to the Southeast Asian NWFZ, citing concerns about its potential restrictions on US transit rights through the zone and EFZS, despite the US having already removed tactical muclear weapons from its surface vessels and aircraft (although it should be noted that the Clinton Administration was faced with a Republic controlled Congress in its later years). US ambivalence intensified under the Bush Administration, which under Ambassador John Bolton's guidance, voted against 26 arms control and disarmament resolutions supported by the overwhelming majority of the intemational community at the 2006 UN General Assembly, while abstaining on a further two, and supporting only three. In the last year of the Clinton Administration, the US opposed or abstained from 28\% of internationally supported arms control resolutions at the UN; by contrast, in 2006, under the Bush Administration, the US opposed or abstained from 90\% of the intemationally supported arms control resolutions. Amongst the internationally endorsed resolutions resisted by America were: support for the establishment of the Central Asia NWFZ (previously supported by the US at the 2004 General Assembly); support for a NWF Southern Hemisphere; convening of a Fourth Special Session of the General Assembly on disarmament; and the promotion of multilateralism in the area of disarmament and non-proliferation.

Extraordinarily, the only countries to vote against the key universal measure to constrain further nuclear proliferation - the Comprehensive 
Test Ban Treaty - were America and North Korea. If North Korea is deemed part of the "Evil Empire" because of its determination to acquire and test nuclear weapons, then the US has seemingly allied itself with that empire in seeking to obstruct the key intemational treaty designed to limit further proliferation - presumably putting its own Pentagon wish list for testing new or modemized types of nuclear weapons ahead of gldbal non-proliferation priorities in such critical regions as the Middle East, Southeast Asia and Northeast Asia.

The contradictory nature of US policy towards NWFZs is even more apparent in its current attitude towards the recently signed central Asian NWFZ Treaty. Considering Central Asia's extensive involvement in nuclear weapon programs of the former Soviet Union, its abundant supplies of uranium, and facilities and technical expertise in processing nuclear fuels, its possession of at least 3 metric tons of weapons grade plutonium at a shutdown breeder reactor in Kazakhstan, and its relatively new polities, with significant potential for instabilities and civil unrest, the US stance seems both illogical and counterproductive. As Jayantha Dhanapala, UN Undersecretary General for Disarmament Affairs, noted, the zone's establishment is "all the more significant given that this region once reportedly hosted over 700 tactical nuclear weapons - not to mention the over 1,400 former Soviet strategic nuclear weapons that Kazakhstan returned to Russia before joining the NPT in 1995" . ${ }^{10}$

From both a regional and global non-proliferation perspective, the need to secure this region from developing nuclear weapons, or exporting fissionable materials to other parts of the world, could scarcely be more urgent.

The C5 regional states spent nine years negotiating the treaty, with the support and expert consultative assistance of the UN and nonproliferation NGOs (such as the Monterey Institute) and extensive consultations with all the nuclear weapon states, especially America and Russia.

At an initial September 1997 conference in Tashkent to establish the zone, the US delegation to the conference was, indeed, very positive about the non-proliferation benefits of the zone:

"The US welcomes the desire of the states of Central Asia to undertake steps toward regional cooperation and security. Careful,

\footnotetext{
${ }^{10}$ Jayantha Dhanapala, UN Undersecretary General for Disarmament Affairs, September 30, 2006, cited in Parish \& Potter, op.cit
} 
deliberate actions that foster regional security will benefit Central Asian states and the international community as a whole. A Nuclear Weapon Free Zone, which can make an important contribution to enhancing regional security, is one element of a regional security system.Another area vital to regional and global security is preventing the spread of nuclear material and across borders; enhanced export control regimes and increased security and protection of nuclear materials, especially in the Newly Independent States of Asia and Europe, can greatly enhance regional and global non-proliferation regimes. We are encouraged by these regional developments and seek to encourage them when appropriate by sharing our arms control experiences and providing technical assistance when asked." ${ }^{11}$

In subsequent years, the US both under the Clinton Administration and even in the initial years of the Bush Administration voted in support of the CANWFZ at successive UN General Assembly, as did the other Western nuclear powers. However, in 2006, the United States not only refused to sign the treaty but actively lobbied against it at the $2006 \mathrm{UN}$ General Assembly, with at least some success with its fellow nuclear club members, Britain and France, who similarly voted against the zone.

So why did the US suddenly conclude in 2006 that all the CANWFZ non-proliferation benefits it had itself identified in 1997 were now to be dismissed, and the zone actually opposed?

At one stage of the negotiations, the US seemed fearful that Iran might join the zone, since the initial draft treaty included the potential expansion to regional neighbours, which include both Iran and Mongolia. Having Iran locked into a binding NWFZ treaty with mandatory standard and additional safeguards (such as the CANWFZ treaty contains) might not seem such an undesirable thing, considering international worries over Iran going nuclear, but it seems the US was worried that, in the short term, Iran would simply use membership of such a zone to promote its peaceful intentions while secretly continuing to develop nuclear weapons. In the end, the Central Asia States listened to the US concems on this, and deleted the clause referring to potential expansion of membership. This was a pity, since neighbouring Mongolia, which in

${ }^{11}$ US Delegation to the Central Asian Nuclear Weapon Free Zone Conference, "Remarks to the Conference", 15-16th September 1997, US State Department, available on NTI/Center for Nonproliferation Studies at the Monterey Institute website, www.nti.org/db/nisprofs/shared/canwfz/usstate.htm. 
1992 had already declared itself a national NWFZ and received international recognition of this status ${ }^{12}$, would have been a welcome addition to the zone, and created a symbolic nuclear-weapon-free swathe across the heart of the Asian landmass.

Despite this concession to US concerns, the US continued to be so deeply perturbed by the treaty as to vote against it and put pressure on its friends to do likewise. The problem from the US point of view lay principally in Article 12 of the treaty which states:

"This Treaty does not affect the rights and dbligations of the Parties under other international treaties which they may have concluded prior to the date of the entry into force of this Treaty. The parties shall take all necessary measures for effective implementation of the purposes and objectives of this Treaty in accordance with the main principles contained therein. ${ }^{\prime 13}$

The US concem lies in the fact that several of the Central Asian States are members of the 1992 Tashkent Treaty with Russia under which the parties agree to provide "all necessary assistance, including military assistance" in response to aggression. This, on the US view, can be interpreted as potentially embracing the possibility of nuclear weapon assistance, which would then be incompatible with the principles of a NWFZ treaty. From a legal point of view, Jozef Goldblat has observed that, in fact, the 1969 Viemna Convention on the Law of Treaties (Article 30) requires that an "earlier treaty" dealing with the same subject matter "applies only to the extent that its provisions are compatible with those of the later treaty" ${ }^{14}$ But, irrespective of the correct legal interpretation of Article 12, the US itself has previously had no difficulties in signing up to NWFZs in which the US itself is a member of military alliances with zonal states, as, for example, the SPNFZ where the US has a bilateral military alliance with Australia in the form of the ANZUS Treaty. Further, its own frequently reiterated "Seven Criteria" for assessing whether a zone should receive US support includes the criterion that "the establishment of the zone should not disturb existing security

\footnotetext{
12 Enkhsaikhan, Jargalsaihan, "Central Asia-Future Perspectives" in Alves, Pericles Gasparini \& Cipollone, Daiana Belinda, (eds.) , Nuclear-Weapon-Free Zones in the 21st Century, UNIDIR, United Nations, Geneva, 1997, pp.96-97

${ }^{13}$ Centre for Non-Proliferation Studies, "Text of the CANWFZ", CNSwebsite, cns.miis.edu/pubs/week/pdf_support/060905_canwfz.pdf

${ }^{14}$ Goldblat, Jozef, "The Treaty of Semipalatinsk has been signed", UNIDIR \& GIPRI, January 242007.
} 
arrangements to the detriment of regional and intemational security or otherwise abridge the inherent right of individual or collective selfdefense guaranteed in the UN Charter. "15 It should also be noted that the Central Asian states, aware of US concems, explicitly included the second sentence in Article 12 referring to effective implementation of the zone principles, which Protocol signatories, such as Russia are also bound to respect under Article 2 of the Protocol.

In summary, it seems that the US and other Western Powers are currently prepared to abandon all the horizontal non-proliferation benefits to be achieved by the CANWF on the basis of a selective principle that Central Asian states should not, in theory, be allowed to call on Russia to defend them with nuclear weapons if faced with extemal aggression, even though, in the case of the South Pacific NWFZ or the proposed denuclearised zone on the Korean Peninsula, America itself reserves the right to use nuclear weapons to defend zonal states (Australia, South Korea) against external aggression, and even though America itself has called for zones to be consistent with existing security arrangements.

Despite the apparent contradictions, and potentially self-defeating implications of the US position (in the sense that the region could potentially become a source to nuclear material exports to US adversaries and non-state groups), the other nuclear powers, with the exception of China, must also bear some responsibility for the impasse. Russia could easily have alleviated American and other Westem power concerns by agreeing not to include Article 12 or, altematively, by itself making a clarifying undertaking in its own signature to the treaty protocol that the military assistance envisaged under the Tashkent Treaty would only extend to conventional rather than nuclear military assistance. Instead, Russia has insisted on securing what it sees as a diplomatic victory over the US rather than taking the opportunity to emphasize its genuine conmitment to the denuclearisation of the Central Asian region.

France and Britain have also recently reversed themselves on the CANWFZ, apparently putting their interest in maintaining good

${ }^{15}$ This criteria, together with the six others, was reiterated by the US State Department Delegation to the Central Asian Nuclear Weapon Free Zone Conference, "Remarks to the Conference", 15-16th September 1997, US State Department, available on NII/Center for Nonproliferation Studies at the Monterey Institute website, www.nti.org/db/nisprofs/ shared/canwfz/usstate.htm. 
relations with the US ahead of global interests in pursuing nonproliferation. Both countries have also been ambivalent on other NWFZ and related initiatives, such as the Southem Hemisphere NFZ initiative and non-use assurances to non-nuclear weapon states. China, of all the nuclear powers, has been the most consistent in supporting NWFZs at the UN, although has conspicuously failed to take confidence building measures in withdrawing nuclear capable missiles from regions close to proposed new NWFZs.

If the challenges of overcoming intraregional conflicts and tensions, and the very counterproductive resistance of many of the nuclear weapon states, are formidable enough, there still remains other major challenges, not least mobilizing the political will to negotiate new NWFZ treaties.

In all the existing successfully negotiated zones, a key factor has been the existence of sufficient political will amongst the governments and diplomats of the regional states to pursue negotiations over extended periods of time.

In most of the zones, adverse past experiences of nuclear activities have been a factor in sensitizing governments and their constituencies to the need for a zone. In Latin America, this was the 1962 Cuban Missile Crisis which nearly engulfed the whole world in nuclear conflagration, and deeply shocked Lat in American governments. In the South Pacific, it was the experience of thirty years of French nuclear testing from 1966 to 1996 in French Polynesia, including eight years of testing in the atmosphere, that concentrated the minds of regional states (Pacific Islands, Australia and New Zealand) on the need to keep nuclear weapons out of the region, whether for testing or for war. In Southeast Asia, previous experiences of wars with superpower involvement, such as Vietnam War during which the US was reported to have considered options for using tactical nuclear weapons, coupled with concems over nuclear transit through the region, were important factors in ASEAN first declaring itself a Zone of Peace, Freedom and Neutrality (ZOPFAN) in 1971 and then establishing the SEANWFZ in 1996. In Africa, many governments were initially concerned over French nuclear testing in Algeria in the early 1960s and later by the South African Apartheid Regime's acquisition of nuclear capabilities and eventually weapons .

In some of the zones, NGO and citizen mobilization has played an important role in influencing the policies of political parties and 
governments, such as the Nuclear Free and Independent Pacific Movement in the South Pacific and its secretariat, the Pacific Concems Resource Centre in Fiji. In some of the more recent zones, such as the African Zone and the Central Asian zone, the UN, its regional centres (such as the UN Regional Centre for Peace and Disarmament in Asia and the Pacific) and its disarmament bodies (including UNIDIR) have played critical research, consultative and resourcing roles in supporting the zone negotiations; and, for all zones the UN has provided international support and legitimation. The tenacity of particular "champions" or advocates of the zonal approach has been crucial, as in the case of the Nobel-prize winning Mexican diplomat, Alfonso Garcia Robles.

Finally, regional organizations, such as the Organization of American States in Latin America, the South Pacific Fonum in the South Pacific, ASEAN in South East Asia have provided important regional fonms for focusing and facilitating the political will to establish NWFZs. While the ways in which this political will is generated will differ greatly from region to region, there is certainly a basis for this in Northeast Asia, the only region of the world to directly experience the use of nuclear weapons in war at Hiroshima and Nagasaki, and where North Korea has now tested its first nuclear device.

A further challenge for both existing and new NWFZs will be to ensure that they keep pace with the rapidly evolving polymorphous nature of proliferation of weapons of mass destruction, not just nuclear, but also in the form of chemical and biological weapons, and the various vectors of delivery, including missiles and radiological dispersal methods. Determined proliferators frequently possess more than one kind of weapon of mass destruction, and more than one modality of delivery. Opponents of the NWFZ could argue, as Israeli has sometimes argued, that nuclear weapons are needed as a deterrent against chemical and biological weapon attacks. This requires both the strengthening of existing zones to link them in better with binding universal treaties or conventions prohibiting unconventional weapons of mass destruction through provisions requiring all member states to ratify the relevant instruments; and the potential inclusion of controls over delivery systems.

A final challenge is to ensure that the zones have very rigorous and effective verification, control and compliance provisions and resources so that all parties can be assured that covert development of nuclear 
weapons is either not possible, or detected in sufficient time and with sufficient sanctions, to ensure that the security of all zonal states is protected. Some of the existing zones need strengthening in this area, with few of the zones established after the Tlatelolco Treaty have specialized agencies comparable to OPANAL to monitor the zone, although all do require IAEA safeguards, and the most recent Central Asia NWFZ has specified the more rigorous IAEA Additional Protocol safeguards developed following recent examples of undisclosed nuclear weapon development programs in some NPT signatory countries.

An associated issue is the availability of treaty compliance sanctions, such as referral of treaty violations to regional bodies or the UN Security Council. The Latin American Tlatelolco treaty empowers the overseeing Treaty General Conference to report on violations not only to the Council of the regional body, the Organization of American States (OAS) but also to the IAEA and the UN Security Council. The most recent Central Asian NWFZ, however, is relatively weaker in this area, since its Article 11 merely specifies that disputes over the application of the Treaty "shall be settled through negotiations or by other means as many be deemed necessary by the Parties".

\section{Opportunities}

The challenges in establishing new NWFZs are formidable indeed, but there are some encouraging developments both internationally and within specific regions, including Northeast Asia, that can facilitate the conditions and political will needed to develop such zones. These opportunities include: the discrediting of unilateral and preemptive approaches to dealing with proliferation and other transboundary security problems, the renewed interest in multilateral approaches, active engagement in regional discussions, if not through a regional body than through extemally facilitated mechanisms, such as the Six-Party talks on North Korea's nuclear program; and the role of NGOs and civil society in mobilizing grassroots constituencies and lobbying key political actors and governments in support of zone establishment.

The chaos and suffering that has ensued from the unilateral US and allied invasion of Iraq over its alleged possession of weapons of mass destruction has demonstrated to much of the international community, and to a majority of the American and British publics, that unilateral and military approaches are not necessarily the solution to global security 
issues, and could well be counterproductive, even from the viewpoint of national self-interest. There was no significant al-Qaeda presence in Iraq before the invasion; now there is such a presence, and the war in Iraq (together with the unresolved Palestinian-Israeli conflict) has become a major factor in increased recruitment for al- Qaeda-style networks. In other key global human security areas, such as climate change and the threat of pandemics (such as Avian Influenza). it has also become obviously to many in the international community that only multilateral approaches will be effective in addressing such problems, and that the UN and its agencies will be crucial in negotiating and coordinating adequate global responses.

In the area of arms control and disarmament, the US Bush Administration, has pursued a highly selective approach as to which multilateral initiatives it will support, conspicuously failing to support such major intemational treaties as the Comprehensive Test Ban Treaty, and weakening the verification mechanisms in the Biological Weapons Convention and proposed conventions on small arms trafficking. It has also, as we have seen, failed to support both the SEANWFZ and the new Central Asian NWFZ proposals. However, the advent of a Democrat-controlled Congress during the present Bush Administration, and the possibility of a Democratic Administration after 2009, creates opportunities for a return to a more multilateral approach to nomproliferation and arms control issues, initially through congressional scrutiny and intervention, and, depending on the outcome of the 2008 election, through the executive function. As one of the most powerful actors in world decision-making, a shift towards more multilateral approaches in the US could have beneficial effects on both close American allies, such as Japan and South Korea, and open up more multilateral avenues through the UN and other regional and international forums.

At a regional level, at least in South Asia and Northeast Asia, there do seem current processes of dialogue that could yield confidence building measures, and, potentially, more extensive regional denuclearisation initiatives. In South Asia, as already mentioned, there is a bilateral dialogue process on nuclear issues between India and Pakistan that commenced at the SAARC Meeting in January 24, and a greater willingness to address the Kashmir issue. In Northeast Asia, the frustrating and difficult Six-Party Talks over North Korea's nuclear stance finally yielded some progress in the form of the February 13 
2007 agreement committing the parties to "early denuclearisation of the Korean Peninsula" and a series of concrete actions that would be taken within 60 days, including a shut-down of North Korea's Yongbyon nuclear facility to be monitored by the IAEA, discussion of a list of all North Korea's nuclear programs, including plutonium holdings; bilateral US-DPRK talks to resolve bilateral issues, with the US beginning the process of removing the designation of the DPRK as a state-sponsor of terrorism and termination of its trade sanctions against DPRK; bilateral Japan-DPRK talks aimed at normalizing relations and settling unresolved matters from past conflicts; and economic, energy, and humanitarian assistance to the DPRK, including an initial shipment of 50,000 tons of heavy fuel oil. While there was a further delay with the 60 day implementation schedule associated with the release of DPRK funds from a Macau Bank, the release of the funds has recently been announced, so there should now be no further impediment to implementation (although past experience with failed Six-Party negotations suggests the need for caution).

Assuming the February 13 Agreement initial steps are indeed implemented, there are a number of further promising aspects of the agreement, particularly the setting up of working groups in such areas as: (1) denuclearisation of the Korean Peninsula; (2) normalization of DPRK-US relations; (3) normalization of DPRK-Japan relations; (4) Economy and Energy Cooperation; and (5) Northeast Asia Peace and Security Mechanism. The last working group is particularly significant as potentially leading to serious consideration of a wider denuclearisation arrangement or NEANWFZ treaty for the whole of Northeast Asia, and potentially also including Mongolia and Taiwan. The involvement of the three key external nuclear weapon states in the form of the US, Russia and china offers the possibility of binding negative and positive security assurances to assure the security of the region against any use or threat of use of nuclear weapons. With this inclusion of the concept of a wider Northeast Asia Peace and Security Mechanism as part of the Six Party regional agenda, there is doviously scope for promoting greater debate and discussion of wider Northeast Asian denuclearisation concepts and proposals, such as the Japan Peace Depot/Pacific Campaign for Disarmament and Security Model Treaty for a Northeast Asia Nuclear-Weapon-Free Zone covering the two Koreas and Japan. 
At an international community level, and despite the ambivalence of some P5 nuclear weapon states, there continues to be strong support for the NWFZ concept as one (but not the only) element in wider strategies for achieving eventual nuclear elimination. Recent examples of this support include the repeated resolutions supporting various forms of regional denuclearisation and nuclear-free zones at UN General Assembly meetings, New Agenda Coalition support for the concept, League of Arab State support, the 2000 Uppsala Conference on Nuclear Weapon Free Zones, and the Tlatelolco 2005 Conference of Existing NWFZ member states, the NGO-initiated Global Partnership for the Prevention of Armed Conflict (GPPAC) meetings, especially the 2004 Tokyo GPPAC regional meeting, and the continued strong support of the UN Secretariat and its disarmament organizations. At the 2005 Tlatelolco Conference, UN Secretary-General Kofi Annan noted the contribution that regional NWFZs made to preventing nuclear proliferation, and called for the creation of new zones in the Middle East and Asia. ${ }^{16}$ This continuing support within the international community will serve to assist any new region considering or seeking to implement NWFZ arrangements, whether through diplomatic support, intemational recognition, or consultative assistance.

Another important force that can successfully address the challenges and obstacles in the path of regional denuclearisation and NWFZ establishment is civil society. Peace and disarmament movements, and associated NGOs, have fluctuated greatly in size depending on the nature of specific crises, wars and threats. They have sometimes been very successful in securing particular arms control advances, like the 1963 Partial Test Ban Treaty outlawing atmospheric testing, the INF ban on intermediate range missiles, and most recently the Ottawa Convention outlawing land mines. In the case of at least one NWFZ, the South Pacific NWFZ negotiated during the Cold War period during 1983-85. Citizen groups and NGOs (such as the Nuclear Free and Independent Pacific Movement) were very effective in lobbying and placing the concept on the regional agenda of political parties and governments, making extensive use of model treaties for lobbying and community education.

\footnotetext{
${ }^{16}$ Annan, Kofi, "Secretary-General's Message to the Conference of States Parties and Signatories of Treaties that Establish Nuclear-Weapon-Free Zones", Tlatelolco, Mexico, April 26th 2005, reproduced on the Critical Will/WILPF website, www.reachingcriticallwill.org/political/nwfz/SGcanfwz.html.
} 
There are now a number of international peace and disarmament NGOS with extensive technical and lobbying expertise in the arms control field, including the Weapons of Mass Destruction Commission, Dag Hammarskjold Foundation, Monterey institute, Greenpeace International, IPPNW, the various peace research and conflict prevention centres, UNIDIR, the International Peace Academy, PCRC, and the GPACC groupings .

In the particular case of Northeast Asia, there are already very active NGOs, such as the Northeast Asia GPPAC-affiliated NGOs which included 50 NGO representatives from Seoul, Beijing, Shanghai, Hong Kong, Taipei, Vladivostok, Ulan Bator, and Japan at its 2005 Tokyo United Nations University Northeast Asia Regional Conference. ${ }^{17}$ The Northeast Asia GPPAC grouping have developed a Northeast Regional Action Agenda ("Tokyo Agenda") which, amongst other initiatives specifically calls for the establishment of a Northeast Asia NWFZ, together with formulation of a Northeast Asia Regional Peace Charter, and creation of a Northeast Asia Regional Organization, and is working to promote civil society dialogues across the region on these proposals. ${ }^{18}$

The civil society initiatives already taken by the GPPAC grouping, the Peace Depot/PCDS Model NEAWFZ Treaty initiative, and neighbouring state initiatives, such as Mongolia's single-state NuclearWeapon-Free Zone declaration, together with a return to multilateral approaches in the wider intemational commity, create the possibility for a very effective NGO-civil society campaign to denuclearize the Northeast Asian region.

\section{Strategies}

The changing context of challenges and opportunities for regional denuclearisation discussed above suggest a number of specific strategies or approaches that would be important in both the short term (next three years) and longer term.

At the UN, it would useful for NGOs to lobby at the 2007 and 2008 for country delegations to the First Committee and General Assembly for the holding of a Fourth Special Session on Disarmament,

\footnotetext{
${ }^{17}$ Kawasaki, Akira, Disarmament and Conflict Prevention: A Civil Society Perspective, Centre for Dialogue, Latrobe University, Working Paper Series 2006, no.2, Melbourne, p.7.

${ }^{18}$ Ibid., pp.12-14
} 
and the convening of a new expert group to look at Nuclear Weapon Free Zones in all their aspects that would then report to this Special Session. The last such expert study was over three decades ago, and a new study would enable fresh thinking to be done both by the regional states and the major powers on the role and contribution of NWFZs. A long overdue Fourth Special Session would potentially seek a renewed commitment from the nuclear weapon states to honour their NPT disarmament obligations as well as addressing the dilemmas posed by new nuclear states, such as Israel, Pakistan, India and North Korea. Associated studies that might be commissioned for a Fourth Special Session would be the effects of nuclear war on specific regions, and more generally on climate. It is doubtful whether the large proportions of people in some South Asia and Middle East countries who appear to support their countries' nuclear weapon ambitions would be so enthusiastic if they were to fully understand the catastrophic and suicidal implications of even a limited nuclear war.

Within each proposed NGO region there is obviously a need to develop support around specific denuclearisation initiatives, such as the Model NEANWFZ Treaty, at both civil and government levels, using multitrack government, academic, NGO discussions and forum, as well as awareness raising campaigns in the relevant constituencies of public and expert opinion.

More specifically, given the central role of the United States by virtue of its global power and influence, and the security relationships it has with states such as South Korea and Japan, there is a specific need to lobby not only the Administration itself but also the US Congress, which can now be expected to be somewhat more open to multilateral arms control initiatives. This might further extend to lobbying and clarifying the positions on NWFZ issues with prospective presidential candidates, whether Democrat, Republican or Independent.

There is also a need to mobilize the "Middle Powers" in support of regional denuclearisation initiatives. The potential of Middle Powers was demonstrated very clearly in Canada's hosting of the Ottawa meetings that culminated in the convention banning land mines. In recent years, there has been some backtracking on commitment to multilateral arms control on the part of some middle powers with close links to the US, such as Canada, Australia and Japan, but the political changes in 
America may well open up possibilities for mobilizing such countries behind new NWFZ initiatives. Related groupings from which support could be mobilized include the New Agenda Coalition and the grouping of existing NWFZ treaty partners.

One concrete possibility might be the convening of a major conference in a North or Central Asian country that would be hosted by the existing NWFZ treaty states, and have as a specific focus the strengthening of existing NWFZs, and the further development of regional and single state NWFZs in Northeast and Southern Asia. 